\title{
Impact of COVID-19 pandemic on brazilian dentists in 2020: an epidemiologic study
}

\author{
Impacto da pandemia de COVID-19 em cirurgiões-dentistas no Brasil no ano \\ de 2020: um estudo epidemiológico
}

\author{
Alessandra Areas e SOUZA ${ }^{a^{*}}$ (D), Juliana Casemiro Ferreira SILVA ${ }^{a}\left(\mathbb{D}\right.$, Bruno Boabaid LOUREIRO $^{\mathrm{b}}$ (D), \\ Elizangela Cruvinel ZUZA ${ }^{\mathrm{a}, \mathrm{b}}$ (D) \\ aUFF - Universidade Federal Fluminense, Instituto de Saúde de Nova Friburgo, Departamento de Formação Específica, \\ Nova Friburgo, RJ, Brasil \\ bUFF - Universidade Federal Fluminense, Instituto de Saúde de Nova Friburgo, Programa de Pós-graduação em \\ Odontologia, Nova Friburgo, RJ, Brasil
}

How to cite: Souza AA, Silva JCF, Loureiro BB, Zuza EC. Impact of COVID-19 pandemic on brazilian dentists in 2020: an epidemiologic study. Rev Odontol UNESP. 2021;50:e20210002. https://doi.org/10.1590/1807-2577.00221

\begin{abstract}
Resumo
Introdução: A pandemia de COVID-19 levou à paralisação das atividades de trabalho em vários setores, gerando uma crise econômica e um alto índice de desemprego em todo o mundo. Objetivo: Avaliar o comportamento e as percepções dos cirurgiões-dentistas brasileiros sobre a pandemia de COVID-19 e verificar seu impacto sobre a rotina do atendimento odontológico. Material e método: Um questionário eletrônico do Google forms foi divulgado por meio das redes sociais no período de julho a novembro/2020. A representatividade para a amostra do estudo foi calculada, gerando um cálculo amostral de 385 dentistas. Resultado: Os resultados mostraram que 318 dentistas $(82,6 \%)$ de todas as regiões do Brasil responderam ao questionário, sendo 112 homens (35,2\%) e 206 mulheres (64,8\%). A maior parte dos entrevistados, ou seja, 249 dentistas $(78,3 \%)$ relataram atuar em consultórios ou clínicas privadas. Dos participantes, 26 $(8,8 \%)$ testaram positivo para COVID-19 e outros $10(3,1 \%)$ tiveram sintomas da doença, porém não fizeram o teste. Nenhum entrevistado relatou ter sido hospitalizado em decorrência à doença. No período de aplicação do questionário, 235 entrevistados estavam atendendo pacientes de rotina e emergência (73,9\%). Apenas 174 (54,7\%) relataram se sentir seguros com o uso dos equipamentos de proteção individual (EPIs). A maior parte dos entrevistados declarou não possuir reserva financeira para a paralisação das atividades de trabalho (54,7\%). Conclusão: A pandemia de COVID-19 teve um grande impacto na odontologia, sendo de fundamental importância um melhor planejamento financeiro, além de reforço constante nos cuidados de biossegurança, para que os profissionais da área possam se resguardar e manter sua prática profissional em tempos de pandemia e incertezas.
\end{abstract}

Descritores: COVID-19; odontologia, Brasil; epidemiologia.

\begin{abstract}
Introduction: The COVID-19 pandemic has led to an interruption in work activities in various sectors, generating an economic crisis and a high rate of unemployment worldwide. Objective: To assess the behavior and perceptions of Brazilian dentists about the COVID-19 pandemic and to verify its impact on the routine of dental care. Material and method: The electronic questionnaire was disseminated through social networks from July to November/2020. The representativeness for the study sample was calculated, generating a sample calculation of 385 dentists. Result: In total, 318 dentists (82.6\%) from all regions of Brazil answered the questionnaire, being 112 men (35.2\%) and 206 women (64.8\%). Most of the interviewees, that is, 249 dentists (78.3\%) reported working in private offices or clinics. Of the interviewees, 26 (8.8\%) tested positive for COVID-19 and another 10 (3.1\%) had symptoms of the disease, but did not take the test. No interviewees reported having been hospitalized due to the disease. During the period of application of the questionnaire, 235 respondents were attending routine and emergency patients (73.9\%). Only $174(54.7 \%)$ reported feeling safe with the use of personal protective equipment. Most
\end{abstract}


interviewees declared that they did not have a financial reserve for the interruption of work activities (54.7\%). Conclusion: The COVID-19 pandemic has had a major impact on dentistry, and better financial planning, in addition to constant reinforcement of biosafety care, which is essential for professionals in the healthcare area, can help to protect them and maintain their professional practice in times of pandemic and uncertainty.

Descriptors: COVID-19; dentistry, Brazil; epidemiology.

\section{INTRODUCTION}

The new coronavirus, Sars-CoV-2 has been identified as the etiologic agent of the disease named COVID-19, which started in Wuhan, China in late 2019 and has spread worldwide. Although the disease, which spreads via the airways and through contact with infected secretions, has low morbidity, it has a high rate of spread and evolution. Those infected by the virus may experience breathing difficulties and/or pneumonia, perhaps presenting the need for the use of mechanical respirators or intubation, with frequent hospitalizations in the intensive care unit (ICU), which creates a major public health problem in the face of limited ICU beds for the care of large populations. ${ }^{1,2}$

On February 26, 2020, the Ministry of Health (MS) confirmed the first case of coronavirus in Brazil, after the carnival. In the same month, the Brazilian federal government decreed a health emergency. On March 11, the World Health Organization (WHO) declared a COVID-19 pandemic. On March 17, the MS confirmed the first death from coronavirus in Brazil. Since then, countless Brazilian cities have implemented quarantine and social isolation, to try to contain the spread of the virus. ${ }^{3-5}$ The most effective preventive measures to reduce the contagion capacity of the new coronavirus are: use of a mask to protect the mouth and nose region, frequent hand hygiene with water and soap or $70 \%$ alcohol gel, identification and isolation of individuals affected by COVID19 or with symptoms, and, for health professionals, the use of personal protective equipment (PPE).

Some Brazilian cities implemented restricted movement of people, with only essential services functioning, which impacted the economy, leading to a high unemployment rate, bankruptcy of micro-entrepreneurs, and stoppage of various commercial activities, thus affecting self-employed professionals, including the dental sector. In the dental area, the COVID-19 pandemic has had a great impact, since this activity carries a great risk of cross-infection, with the use of frequent aerosols and close interpersonal contact, which may lead to the further spread of the virus. ${ }^{4}$

The Federal Council of Dentistry (CFO) prepared recommendations for dental appointments for the safe care of patients in this period, prioritizing emergencies. ${ }^{6}$ After a few months of stoppage, routine appointments were reinstated, following strict biosafety protocols; however, the adaptation of professionals to the new routine and the constant fear of contamination perpetuates among dentists. ${ }^{6}$

In view of these considerations, the objective of this research was to evaluate the behavior and perceptions of Brazilian dental surgeons about the COVID-19 pandemic and to verify its impact on the routine of dental care.

\section{METHODOLOGY}

\section{Study Design and Ethical Issues}

A cross-sectional epidemiological study was conducted with online questionnaires, sent through Google Forms, via email, WhatsApp or social networks (Facebook ou Instagram). The 
questionnaire was available from July to November 2020. The research was approved by the Research Ethics Committee of the Health Institute of Nova Friburgo under number 4,097,152. The study was conducted in accordance with the requirements of the Declaration of the Medical Association of Helsinki. ${ }^{7}$ The Free and Informed Consent Form was sent together with the questionnaire, via Google Forms, and the participants consented to participate voluntarily.

\section{Sample Selection}

Data from the Federal Council of Dentistry (CFO) from 2020 show that over 344 thousand dentists work in the national territory. ${ }^{8}$ The representativeness for the study sample was calculated by an website, ${ }^{9}$ with a $95 \%$ confidence level and a $5 \%$ margin of error, generating a sample calculation of 385 dentists.

Representative samples of professionals from each region of the country were calculated, according to the number of professionals enrolled in each Regional Dentistry Council (CRO) obtained from CFO data, ${ }^{8}$ in order to have a representative number from all over the country. The only inclusion criterion was to be a trained dental surgeon, with a registration in the CRO of the relevant state. There were no exclusion criteria. To reach the calculated representative number, approximately 1,000 questionnaires were sent, randomly, considering an estimated response rate of $40 \%$.

\section{Data Collection}

Individuals received the questionnaire link through Google Forms. ${ }^{10}$ Links were sent to dentists throughout Brazil via social networks and friend networks of the researchers, until the required number was reached. Participation was voluntary. The questions were objective, with few discursive items, which could be completed or not, at the discretion of the interviewees. The 26 questions involved items such as time since graduation, areas of expertise, impact of the pandemic on clinical practice, modification of the routine, care with biosafety, and feelings about the future, among others.

\section{Statistical Analysis}

The results were analyzed in a descriptive manner, using absolute and relative frequencies. The mean was also used as a measure of central tendency and standard deviation as a measure of dispersion of values. The data were transferred to an Excel spreadsheet for analysis and the results are expressed as a percentage.

\section{RESULT}

From the initial estimated sample ( $\mathrm{n}=385$ dentists), 318 responses were obtained, with the voluntary participation of $82.6 \%$ of the sample, made up of 112 men (35.2\%) and 206 women (64.8\%). Considering the regions of Brazil, the responses to the questionnaire were as follows: Midwest ( $n=33 ; 10.4 \%)$, Federal District $(n=17 ; 5.3 \%)$, Southeast $(n=173 ; 54.4 \%)$, North $(n=22$; $6.9 \%)$, Northeast $(n=39 ; 12.3 \%)$, and South $(n=34 ; 10.7 \%)$ (Table 1$)$. 
Table 1. Sample of dental surgeons (DSs) by region of Brazil

\begin{tabular}{cccc}
\hline REGION & DSs & INTENDED SAMPLE & FINAL SAMPLE \\
\cline { 4 - 4 } & & 30 & NUMBER (\%) \\
\hline NORTH & 19,667 & 65 & $22(73.3)$ \\
NORTHEAST & 58,172 & 25 & $39(60.0)$ \\
MIDWEST & 22,326 & 185 & $33(132.0)$ \\
SOUTHEAST & 181,059 & 65 & $173(93.5)$ \\
SOUTH & 55,240 & 15 & $34(52.3)$ \\
FEDERAL DISTRICT & 8,084 & $\mathbf{3 8 5}$ & $17(113.3)$ \\
TOTAL & $\mathbf{3 4 4 , 5 4 8}$ & & $\mathbf{3 1 8 ( 1 0 0 . 0 )}$ \\
\hline
\end{tabular}

Source of data for dental surgeons (DSs) Brazil: CFO (2020) ${ }^{8}$

The majority of respondents were between $41-50$ years ( $n=93 ; 29.2 \%$ ), followed by $22-30$ years $(n=83 ; 26.1 \%)$ and $31-40$ years $(n=74,23.3 \%)$. Most participants had at least one specialization ( $\mathrm{n}=251,79.9 \%)$. The most cited areas of activity were, respectively, Odontology $(\mathrm{n}=184 ; 57.9 \%)$, Prosthesis ( $\mathrm{n}=147 ; 46.2 \%)$, and Periodontology $(\mathrm{n}=101 ; 31.8 \%)$.

The majority of respondents reported working in private offices or clinics $(n=249)$. In addition, 128 interviewees declared themselves to be civil servants, at the municipal $(n=62)$, state $(\mathrm{n}=50)$, and federal $(\mathrm{n}=16)$ levels. Of the public employees, 59 also worked in the private sector.

Of the responses obtained, 28 dentists (8.8\%) reported having tested positive for COVID-19, 21 with mild symptoms and seven with moderate symptoms. Another 10 dentists (3.1\%) had symptoms of the disease, but did not take the test. Of the 318 dental surgeons, 280 (88\%) did not report having the disease. When evaluating the presence of comorbidities, 83 participants $(26.1 \%)$ reported having at least one comorbidity, the main ones being arterial hypertension and obesity (Figure 1A). None of the interviewees stated that they had been hospitalized due to the disease.

In the period of application of the questionnaire, from July to November 2020, most respondents were attending routine and emergency patients $(235 ; 73.9 \%)$, another $11(3.4 \%)$ professionals were attending only emergencies, and $72(22.6 \%)$ were not attending patients. The majority ( $\mathrm{n}=138 ; 43.3 \%$ ) reported having reduced the number of routine patients to up to five daily visits. The low demand for routine care by patients was also reported by 139 (43.7\%) respondents.

Of the interviewees, 95 (29.9\%) reported being afraid of the future and $14(4.4 \%)$ said they were distressed, however, the majority $(231 ; 72.6 \%)$ were optimistic about the future of dentistry and $273(85.8 \%)$ believed in a gradual return to routine activities. Regarding future perspectives for professional practice, the answers are described in Figure 1B.

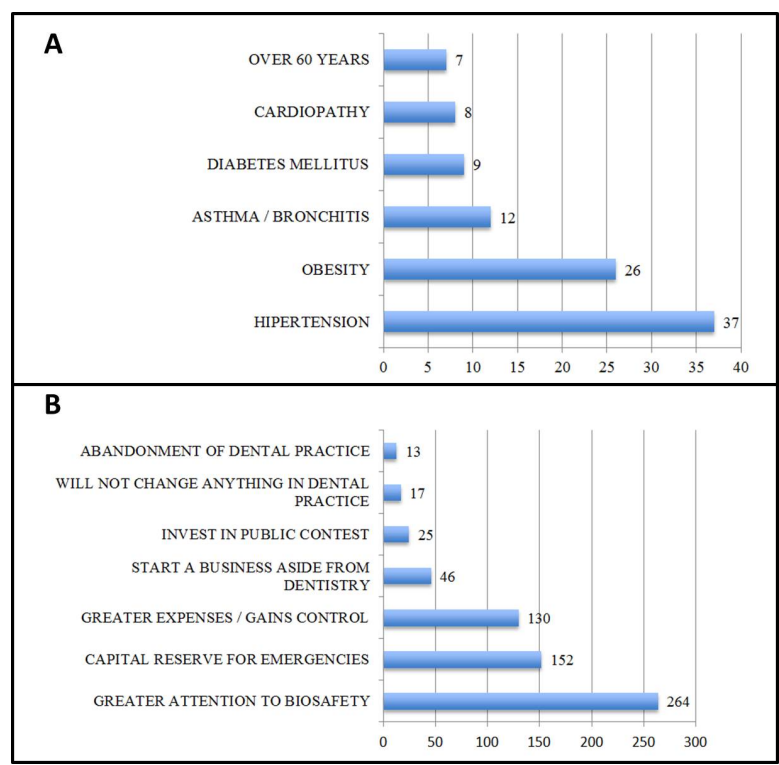

Figure 1. (A) Comorbidities reported by dentists; (B) Changes in dental practice and future prospects; $(n=318)$. 
Of the participants, $224(70.4 \%)$ answered that they trust the adopted biosafety protocols, however, only 174 (54.7\%) reported feeling safe with the use of PPE and 143 (45\%) dentists pointed out difficulty in adapting to using a Face Shield. Another issue raised was the increase in PPE costs. Regarding the adequacy of patient attendance, it was found that the biosafety measures were reinforced (Table 2).

Table 2. Biosafety care adopted by dentists who provided routine/emergency dental care $(n=246)$

\begin{tabular}{cc}
\hline Disinfection of surfaces for each appointment & $246(100 \%)$ \\
Personal Protective Equipment on staff and patients & $246(100 \%)$ \\
Empty waiting room or with one patient at a time & $221(89.8 \%)$ \\
Change of Personal Protective Equipment at each service & $185(75.2 \%)$ \\
COVID-19 symptoms health questionnaire & $164(66.6 \%)$ \\
Measurement of patient temperature & $136(55.2 \%)$ \\
Mouthwash with hydrogen peroxide prior to attending patients & $133(54 \%)$ \\
Avoid aerosol production (high speed/ultrasound) & $119(48.3 \%)$ \\
\hline
\end{tabular}

Regarding having a financial reserve for the interruption of activities during the pandemic, $117(36.8 \%)$ dentists claimed to have some financial reserve, while the majority $(174 ; 54.7 \%)$ reported that they did not have any reserves to remain out of the routine of work. Some research participants preferred not to answer this question $(27 ; 8.5 \%)$.

During the period of social isolation and circulation restriction, which varied between cities in the country, with an average duration of between two and three months, 188 (59.1\%) participants reported having taken the opportunity to study and attend dentistry lectures on social networks in order to update themselves on various subjects.

\section{DISCUSSION}

Despite the efforts of researchers to send invitations to participate in the survey through social networks, personal contacts, and e-mails, the estimated sample number $(\mathrm{n}=385)$ was not reached, thus 318 volunteers (82.6\%) responded to this research. While in some regions of Brazil more than the required responses were obtained, such as in the Midwest $(n=33 ; 132 \%)$ and the Federal District ( $\mathrm{n}=17 ; 113.3 \%)$, other regions fell short, which was observed in the North $(22 ; 73.3 \%)$, Northeast $(39 ; 60 \%)$, Southeast $(173 ; 93.5 \%)$, and South $(34 ; 52.3 \%)$ regions. This fact may be explained by some factors, for example, when there were duplicate responses to the questionnaire, they were excluded from the sample, which occurred frequently in the North and Southeast regions. Another issue to be considered is the large territorial area of Brazil, divided into six regions, with different cultures, some of which are more receptive than others. This may have directly influenced the return of the questionnaires to the researchers, who sent the questionnaire to all regions, including the Northeast and South.

The global economic scenario of insecurity and fear regarding employment and the provision of services was also reflected in Brazilian dentists. This insecurity was expressed by the report of fear of the future $(95 ; 29.8 \%)$ and distress $(14 ; 4.4 \%)$ by some interviewees. The increase in cases of depression and anxiety rose sharply in the year 2020, reaching people of all ages and social classes. ${ }^{11}$ The uncertainties about the future and fear of the disease, along with social isolation observed in our sample, direct attention to the importance of making mental health programs, via the Unified Health System (SUS), available to the entire population, with an emphasis on programs aimed at health professionals. 
On the other hand, the majority of participants $(231 ; 72.6 \%)$ were optimistic. This fact can also be explained by the diversity of Brazilian culture, which, regardless of religion, has great credulity and faith that may have corroborated the reported optimism, although there was no specific question on this topic in the questionnaire applied. According to the demographic census of the Brazilian Institute of Geography and Statistics, Roman Catholicism predominates in Brazil with 64.6\%, followed by Protestantism (22.2\%), atheism (8\%), other religions (3.2\%), and Spiritualism $(2 \%) .^{12}$

The rapid rate of propagation and dissemination of the virus puts dental professionals at constant risk of infection, due to close contact with the oronasal, oropharyngeal complex and the patient's salivary secretion, both in the service itself and in the aerosols disseminated in the air. Despite this scenario, the rate of contamination of dentists by SARS-COV2 has been low so far, considering the national report presented by the Ministry of Health, at the request of the CFO, to monitor the evolution of cases of contamination with the virus among dental professionals. 5,13,14 According to the national report of the Ministry of Health, in the total number of people infected in Brazil from March to June 2020, 0.17\% were dental surgeons, which represented 2,737 infected professionals, out of the national total of 1,603,055 people infected. In addition, of the 169 deaths of health professionals registered in Brazil between March and June 2020, five were dental surgeons. ${ }^{5}$ There was a significant increase in contamination and deaths by COVID-19 among health professionals after August 2020 across Brazil. These data corroborate our findings which demonstrated that of the 318 dentists interviewed from July to November 2020, 28 (8.8\%) reported testing positive for COVID-19, a percentage higher than that obtained in the period of the MS report, which was from March to June 2020, demonstrating the rapid rate of spread of the virus.

A small portion of the sample presented risk factors for COVID-19, with the most prevalent comorbidities being arterial hypertension and obesity. It is important to promote a program to control occupational health and risk factors, with incentive for physical activity, good nutrition, and good sleep habits, which can help to improve the quality of life of dental professionals, in addition to removing them from the risk group for COVID-19.

The strategies to prevent the spread of COVID-19 among health professionals were highlighted in Technical Note No. 7/2020, of the National Health Surveillance Agency (ANVISA), which addressed several epidemiological surveillance measures in medical institutions. ${ }^{15}$ Routine biosafety care is already a constant practice in dentistry. ${ }^{15}$ Thus, according to the ANVISA recommendations, the adequacy of care focused on limiting aerosol production, greater air circulation in the offices, more frequent exchange of PPE, spacing between consultations for the disinfection of all surfaces, empty waiting rooms, temperature measurement, patient symptom questionnaires, and using a mouthwash with hydrogen peroxide or chlorhexidine before the appointment. ${ }^{15-17}$ The results of the present study corroborate with the recommendations of ANVISA $^{15}$ and $\mathrm{CFO}^{18}$, as the majority of dentists reinforced the care with biosafety during routine dental/emergency care, despite reporting difficulties with adaptation to the Face Shield.

Depending on the dental specialty practiced, a greater amount of infectants and aerosols can be produced. In routine dental consultations, there is a low possibility of contamination, while surgical procedures using turbines or periodontal care, with ultrasound, represent a high risk of aerosol production and viral spread. The postponement of elective procedures and the execution of only emergency treatments was one of the measures recommended by the CF0.6 It should be noted that patients with chronic diseases, such as periodontitis, were prejudiced with respect to the regular maintenance, which should be performed at intervals of 3 to 6 months. Thus, a possible worsening of the disease may have occurred during this period, added to behavioral factors such as increased smoking, anxiety disorders, alcohol consumption, and carelessness with personal hygiene. 
Although Brazil has a large number of dentists, with the proliferation of many dental schools authorized by the Ministry of Education over the years, IBGE (Brazilian Institute of Geographic and Statistics) data estimate that approximately 30 million Brazilians have never been to the dentist and a minimal part of the population has regular access to public $(21.6 \%)$ or private (9.4\%) dental services. ${ }^{12}$ In the sample surveyed, most dentists worked in the private sector and a minority were civil servants. The discrepancy in the number of self-employed professionals and the lack of access to private services for most of the population help to explain that the economic crisis in the sector, which already existed, only worsened further due to the pandemic.

The interruption in economic activities brought to the fore the need for greater attention to teaching and practice of financial management and administration to dental professionals. Many dentists $(54.7 \%)$ reported not having financial reserves to cover their fixed costs in the period of stoppage, which would have generated debt for these professionals. The importance of having money set aside for emergencies, working capital, as well as reducing office expenses needs to be emphasized and, if the professional is not involved in the administrative part of the business, there is a need for a manager or administrator, to ensure financial health, with an estimate of all fixed and variable costs, so that the gross gain includes an acceptable net gain, compatible with the professional's life expectations, in addition to guaranteeing a monthly reserve fund to guarantee good dental practice. ${ }^{19}$

In this period of pandemic, an increase in the prices of PPE was also observed, which was also reported by the participants of our study, making it difficult for professionals to meet them or implying the transfer of costs to the patient, with an increase in prices. The CFO has taken a stand with consumer protection agencies against this abusive price increase. ${ }^{20}$

An increase in the use of social networks and virtual contact has created a new scenario of digital education and remote teaching, opening doors to new forms of distance education and teleodontology. ${ }^{21}$ During this period, dentists received many offers of online courses and classes. In our research, many dentists reported having studied during this period, seeking professional improvement in the midst of the crisis.

It is important to highlight the importance of the role of the CFO and professional associations, in defense of dental professionals, promoting reports, actions to search for credit lines, suspension of payments of student financing and postponement of taxes. The CFO worked together with ANVISA in the preparation of technical standards for dental care to guide SUS and private service professionals (Technical Note GVIMS / GGTES / ANVISA No. 04/2020), as well as acting in the constant dissemination of information. ${ }^{4,15,18}$

Brazil, together with the rest of the world, realized the importance of investing widely in science and technology for health, promoting research on medications and vaccines, on immune mechanisms, and on the spread of new microorganisms. The production and dissemination of knowledge in the health field is essential for future pandemics to be prevented.

In an unpredictable and historic event and a world scenario of uncertainties, pending mass vaccination and pandemic control, life continues to adapt to the new scenario and the use of available therapeutic tools, which include, in addition to early diagnosis and medications, social distancing, wearing masks, and constant hand disinfection. A panorama of the global economic and humanitarian crisis is emerging, with a record number of unemployed people and the need for action by municipal, state, and federal governments to assist those in need, to avoid hunger and increasing violence. The impact on everyone's life is immense, but the work on recovery must be a joint, supportive, and constant effort, aiming at the return to routine activities. 


\section{CONCLUSION}

The COVID-19 pandemic has had a great impact on dentistry, since this activity carries a large risk of cross-infection, with the use of frequent aerosols and close interpersonal contact, being that, better financial planning and constant reinforcement of biosafety care are essential so that professionals in the area can protect themselves and maintain their professional practice in times of pandemic and uncertainty.

\section{ACKNOWLEDGMENT}

The authors would like to thank PROPPI/UFF (Dean of Research, Graduate Studies and Innovation/Federal Fluminense University) for the scholarships granted to students Juliana Casemiro Ferreira da Siva and Bruno Bouabaid Loureiro in the Public Notice for the selection of research, teaching and extension projects aimed at tackling the pandemic of COVID-19 (PROPPI PROGRAD - PROEX № 04/2020).

\section{REFERENCES}

1. Cheng ZJ, Shan J. 2019 Novel coronavirus: where we are and what we know. Infection. 2020 Apr;48(2):155-63. http://dx.doi.org/10.1007/s15010-020-01401-y. PMid:32072569.

2. World Health Organization. Novel Coronavirus - China. Disease outbreak news : update [Internet]. Geneva: WHO; 2020 [cited 2021 Jan 5]. Available from: https://www.who.int/csr/don/12-january2020-novel-coronavirus-china/en/

3. World Health Organization. Novel Coronavirus (2019-nCoV) technical guidance [Internet]. Geneva: WHO; 2020 [cited 2021 Jan 5]. Available from: https://www.who.int/emergencies/diseases/novelcoronavirus-2019/technical-guidance

4. Cavalcante JR, Cardoso-Dos-Santos AC, Bremm JM, Lobo AP, Macário EM, Oliveira WK, et al. COVID-19 no Brasil: evolução da epidemia até a semana epidemiológica 20 de 2020. Epidemiol Serv Saude. 2020;29(4):e2020376. http://dx.doi.org/10.5123/S1679-49742020000400010. PMid:32785434.

5. Brasil. Ministério da Saúde. Painel de casos de doença pelo coronavírus 2019 (COVID-19) no Brasil pelo Ministério da Saúde [Internet]. Brasília: Ministério da Saúde; 2020 [cited 2020 May 14]. Available from: https://covid.saude.gov.br/

6. Brasil. Conselho Federal de Odontologia. COVID-19 e odontologia - medidas para aumentar a segurança de pacientes e profissionais [Internet]. Brasília: CFO; 2020 [cited 2020 Dec 30]. p. 1-35. Available from: http://cro-ce.org.br/upload/E-Book CFO Versão Dezembro 2020.pdf

7. World Medical Association. World Medical Association declaration of Helsinki: ethical principles for medical research involving human subjects. JAMA. 2013 Nov;310(20):2191-4. http://dx.doi.org/10.1001/jama.2013.281053. PMid:24141714.

8. Brasil. Conselho Federal de Odontologia. Quantidade geral de profissionais e entidades ativas [Internet]. Brasília: CFO; 2020 [cited 2020 Dec 3]. Available from: https://website.cfo.org.br/estatisticas/quantidade-geral-de-entidades-e-profissionais-ativos/

9. SurveyMonkey. Calculadora de tamanho de amostra [Internet]. 2020 [cited 2020 Dec 20]. Available from: https://pt.surveymonkey.com/mp/sample-size-calculator/

10. Google Forms. Formulários [Internet]. 2020 [cited 2020 Dec 20]. Available from: https://docs.google.com/forms

11. Stein MB. Editorial: COVID-19 and anxiety and depression in 2020. Depress Anxiety. 2020 Apr;37(4):302. http://dx.doi.org/10.1002/da.23014. PMid:32266767. 
12. Instituto Brasileiro de Geografia e Estatística - IBGE. Censo Demográfico 2010: características gerais da população, religião e pessoas com deficiência [Internet].Rio de Janeiro: IBGE; 2010 [cited 2020 Dec 30]. p. 1-215. Available from:

https://biblioteca.ibge.gov.br/visualizacao/periodicos/94/cd_2010_religiao_deficiencia.pdf

13. Banakar M, Bagheri Lankarani K, Jafarpour D, Moayedi S, Banakar MH, Mohammadsadeghi A. COVID19 transmission risk and protective protocols in dentistry: a systematic review. BMC Oral Health. 2020 Oct;20(1):275. http://dx.doi.org/10.1186/s12903-020-01270-9. PMid:33032593.

14. Passarelli PC, Rella E, Manicone PF, Garcia-Godoy F, D'Addona A. The impact of the COVID-19 infection in dentistry. Exp Biol Med (Maywood). 2020 Jun;245(11):940-4. http://dx.doi.org/10.1177/1535370220928905. PMid:32436748.

15. Brasil. Ministério da Saúde. Agência Nacional de Vigilância Sanitária - ANVISA. NOTA TÉCNICA GVIMS/GGTES/ANVISA No 04/2020 - revisada em 08/05/2020. Orientações para serviços de saúde: medidas de prevenção e controle que devem ser adotadas durante a assistência aos casos suspeitos ou confirmados de infecção pelo novo coronavírus (Sars-cov-2) [Internet]. Brasília: ANVISA; 2020 [cited 2021 Jan 6]. Available from:

https://www20.anvisa.gov.br/segurancadopaciente/index.php/alertas/item/nota-tecnica

16. Gallagher JE, Johnson I, Verbeek JH, Clarkson JE, Innes N. Relevance and paucity of evidence: a dental perspective on personal protective equipment during the COVID-19 pandemic. Br Dent J. 2020 Jul;229(2):121-4. http://dx.doi.org/10.1038/s41415-020-1843-9. PMid:32710059.

17. Burton MJ, Clarkson JE, Goulao B, Glenny A-M, McBain AJ, Schilder AG, et al. Use of antimicrobial mouthwashes (gargling) and nasal sprays by healthcare workers to protect them when treating patients with suspected or confirmed COVID-19 infection. Cochrane Database Syst Rev. 2020 Sep;9:CD013626. http://dx.doi.org/10.1002/14651858.CD013626.pub2. PMid:32936949.

18. Brasil. Conselho Federal de Odontologia. COVID-19 e odontologia - medidas para aumentar a segurança de pacientes e profissionais [Internet]. Brasília: CFO; 2020 [cited 2020 Dec 30]. p. 1-35. Available from: http://cro-ce.org.br/upload/E-Book CFO Versão Dezembro 2020.pdf

19. Balaji SM. COVID-19 - future of dentistry. Indian J Dent Res. 2020 Mar-Apr;31(2):167-8. http://dx.doi.org/10.4103/ijdr.IJDR_347_20. PMid:32436891.

20. Brasil. Conselho Federal de Odontologia. CFO busca coibir aumento abusivo de preços de EPIs junto aos órgãos responsáveis [Internet]. Brasília: CFO; 2020 [cited 2020 Dec 20]. Available from: https://website.cfo.org.br/cfo-busca-coibir-aumento-abusivo-de-precos-de-epis-junto-aos-orgaosresponsaveis/

21. Goel A, Gupta L. Social media in the times of COVID-19. J Clin Rheumatol. 2020 Jun;26(6):220-3. http://dx.doi.org/10.1097/RHU.0000000000001508. PMid:32852927.

\section{CONFLICTS OF INTERESTS}

The authors declare no conflicts of interest.

\section{${ }^{*}$ CORRESPONDING AUTHOR}

Alessandra Areas e Souza, UFF - Universidade Federal Fluminense, Rua Dr. Silvio Henrique Braune, 22, Centro, 28625-650 Nova Friburgo - RJ, Brasil, e-mail: alessandraareas@id.uff.br

Received: January 15, 2021

Accepted: February 4, 2021 